\title{
An Investigation of Tertiary EFL Teachers' Problems in Their In-service Professional Development
}

\author{
Junyi Meng \\ School of Foreign Languages, Institute of Social Technology, Suranaree University of Technology, Nakhon Ratchasima, \\ Thailand \\ Songphorn Tajaroensuk \\ School of Foreign Languages, Institute of Social Technology, Suranaree University of Technology, Nakhon Ratchasima, \\ Thailand
}

\begin{abstract}
The developing trend and reform in the field of Teaching English as a Foreign Language (TEFL) have updated the requirements for tertiary EFL teachers. To meet these requirements, the teachers are encouraged to have their in-service professional development. However, the current situation of their in-service professional development is not as good as what has been expected. Hence, this study aimed at investigating the problems that tertiary EFL teachers may have in their in-service professional development and the suggestions that they made for helping to solve these problems. The data was collected from questionnaire and semi-structured group interview which were responded by the EFL teachers in Guiyang University of China. The findings after data analysis showed that the tertiary EFL teachers had such problems as the limitation of programs, the discontinuity of programs, the inappropriateness of programs, etc. and they suggested that the cooperation with colleagues should be employed in their in-service or on-the-job professional development.
\end{abstract}

Index Terms - in-service professional development, tertiary EFL teachers, problems, suggestions

\section{INTRODUCTION}

The worldwide expansion in the use of English language has brought with new requirements and standards of Teaching English as a Foreign Language (TEFL). So there is a much higher level of professionalism in TEFL today than previously (Richard, 2008). The improvement of the EFL teachers' professionalism level depends greatly on their professional development, especially their in-service professional development. As early as in the 1970s, James (1973) ascertained that "it is only through the growth of in-service training that this gulf between advancing knowledge and practice can be bridged" (p.15). In the profession of teaching, more researchers stressed the importance of teachers' in-service professional development, such as in Widden et al.'s (1996) and in Day's (1999) studies, they claimed that as a result of the considerable change in education which makes enormous production in knowledge and information, the nature of teaching also demands teachers to engage in utilizing this knowledge effectively and it needs continuing career-long professional development role of the teacher in changing contexts in which teachers work and learning takes place. The rapid development of China leads to the situation that English is noted as the most learnt foreign language in China. Hence, the effectiveness and efficiency of English learning and teaching in China at all educational levels draw significant attention from stakeholders (Li \& Hudson, 2011). In order to adapt to the new situation, China's Ministry of Education (MOE) has attached more importance to the TEFL in higher education, and improved the "Syllabus for English Majors of Colleges or Universities" in 2001 and issued the "College English Curriculum Requirements" in 2006. To be in accordance with the rules or norms in such requirements, the EFL teachers are encouraged to have their on-the-job professional development.

The EFL teachers in tertiary education in China can be generally divided into two groups: one of them teaches General English (GE) to non-English major students; the other teaches both General English and some specialized courses to English major students. Such skills are usually involved in General English as listening, speaking, reading, writing, and even translating. Besides, the specialized courses for English majors mainly include introduction to linguistics, American and British literature, translation theory and practice between Chinese and English, Chinese and Western culture comparison, etc. Tertiary EFL teachers in China are required to finish both teaching and research work. In most cases, those English teachers working with the non-English majors have heavier teaching load than those with English majors, whereas the latter, most of whom have a specific research focus, has more tendency to deal with their research than the former. However, since the year of 1998, China has increased its college enrollment, during the 1996-2000 period there was a total enrollment of over 11 million, from 2001 to 2005 the number of university students would be up to 16 million (CERNET, 2001, as cited in Meng \& Tajaroensuk, 2013). It is evident that no matter what 
group they belong to, Chinese tertiary EFL teachers now have much more teaching load than ever.

In fact, the nature of EFL teacher knowledge or professional knowledge seems to be a kind of transient knowledge, which needs to be updated with the inevitable change of the society. The gap between what the EFL teachers need to update and what they have already had in terms of professional knowledge should be bridged, and one of the best ways is by their in-service or on the-job professional development.

However, to conduct the in-service professional development is found to be faced with difficulties. Although many programs or models have been offered to help EFL teachers with their in-service professional development, most of them were not found to be as efficient as what had been planned. Ono and Ferreira (2010) have pointed out that many models of professional development do not achieve their ambitious learning goals. Quite a few researchers (Fullan \& Hargreaves, 1996; Ball \& Cohen, 1999; Collinson \& Ono, 2001; Feiman-Nemser, 2001; Villegas-Reimers, 2003; Schwille \& Dembélé, 2007) found that traditional in-service teacher professional development programs are delivered in the form of workshops, seminars, conferences or courses, which have been criticized as being brief, fragmented, incoherent encounters that are decontextualised and isolated from real classroom situations (as cited in Meng, Tajaroensuk \& Seepho, 2013). Such dissatisfaction was also observed in Chinese tertiary EFL teacher in-service professional development. Liu (2005) and Zheng (2010) had the findings in their research that showed a theoretical, academic, or research-oriented way is frequently applied to train Chinese EFL teachers, which leads to their passiveness. Zhang and $\mathrm{Li}$ (2003) and Liu (2006) claimed that when the teachers are asked to comment on these training programs, they criticized the distance between theory and practice. In addition, Wen and Ren (2010) also found in their survey that by reviewing the characteristics of the literature concerning the tertiary EFL teacher in-service professional development in China from the year of 1999 to 2009, many problems were linked to such limitations as being isolated from EFL classrooms and neglecting the teachers' demands (as cited in Meng, Tajaroensuk \& Seepho, 2013).

Therefore, this study aims at investigating the current problems that the tertiary EFL teachers have in their in-service professional development and the suggestions that they make on it, and then to help solve these problems. The authors took the followings as the research questions of this study.

1. What are the tertiary EFL teachers' current problems in their in-service professional development?

2. What are the suggestions that the tertiary EFL teachers made for their in-service professional development?

\section{ReSEARCH Methodology}

\section{A. Participants}

55 EFL teachers, including 29 from the Department of College English Teaching and 26 from the School of Foreign Languages at Guiyang University of China, participated in this present study. The former group teaches English to non-English major students, while the latter one teaches English majors. All of them responded to the questionnaire, but only 12 of them were selected as the interviewees in the semi-structured interview in group. The participants were selected on the basis of purposiveness and availability.

\section{B. Instruments}

Two instruments were employed for data collection, namely, a questionnaire and a semi-structured group interview. A questionnaire was designed to find out the problems that the tertiary EFL teachers have in their in-service professional development and obtain the suggestions that they can offer. Meanwhile, a semi-structured group interview was also used to find more in-depth information about the teacher participants' problems and opinions on their in-service professional development, and the suggestions they could make on this issue.

\section{Data Collection}

First, the questionnaire took all of the 55 teacher participants as the respondents who was asked to answer both closed-end and open-ended questions. Three parts were included in this questionnaire. Part I is participants' personal information, such as sex, age, educational background, teaching experiences, teaching levels, etc. Part II is made up of the statements and open-ended questions on the problems that the teacher participants may encounter in their own professional development. Part III consists of the statements and open-ended questions about their suggestions and the needs on a model for tertiary EFL teachers' in-service professional development. 5-point Likert scale was used to design the closed-ended questions according to their level of agreement. Values on the scale are strongly disagreed, disagree, uncertain, agree, and strongly agree. The information from this questionnaire was analyzed and prioritized to indicate the current problems of tertiary EFL teachers in their in-service professional development from the highest to the lowest.

Second, the semi-structured group interview took the 12 teacher participants who would be involved in the experiment which is the follow-up research of this present study as the interviewees. Some questions were asked in this interactive group setting where the teacher participants were free to talk with other group members. The questions consisted of the teacher participants' opinions on current problems of in-service professional development and their suggestions on how to improve the ways to in-service professional development.

\section{Data Analysis}




\section{Quantitative Data Analysis}

In terms of the quantitative data from the Likert Questionnaire, the statistical way was adopted for analyzing the data, exactly, the fifty-five teacher participants' responses in the Likert Questionnaire were analyzed by the frequencies for the level of their agreements.

2. Qualitative Data Analysis

Regarding the qualitative data from the open-ended questions in the questionnaire and the semi-structured group interview, the qualitative analysis methods were employed. While analyzing the data from the open-ended questionnaire, the data were already the written texts and then could be directly progressed according to the steps of the qualitative data analysis. By analyzing the data, the researcher found the current problems that the tertiary EFL teachers have in their in-service problems, and the suggestions that they offered for their in-service professional development. While analyzing the data from the semi-structured group interview, the audio-taped data, first of all, were transcribed with several times of listening in order to have their reliability. Followed by the other steps of qualitative analysis, the interview data offered more in-depth information on the problems of the participants in their in-service professional development, and the suggestions or opinions on the needs to design practical programs or develop a model.

\section{RESULTS}

After analyzing the data collected from the instruments, the authors presented and interpreted the results in accordance with the research questions of this study.

In response to Research Question 1, the results were presented according to the instruments respectively.

\section{A. The Results from the Questionnaire}

The investigation was conducted through the questionnaire that was made up of both closed-ended and open-ended questions. Firstly, according to their level of agreement, the teacher participants rated on 5-point Likert scale about the problems that they met with in their in-service professional development.

TABLE 1;

THE RESULTS OF TERTIARY EFL TEACHER S' PROBLEMS IN THEIR IN-SERVICE PROFESSIONAL DEVELOPMENT

\begin{tabular}{|c|c|c|}
\hline Problems & M & SD \\
\hline 1. There are quite limited programs for tertiary EFL teachers for their in-service professional development. & 4.60 & 0.49 \\
\hline $\begin{array}{l}\text { 2. Implementing EFL teacher in-service professional development costs the university more because most } \\
\text { of the programs are offered in other cities or areas }\end{array}$ & 4.39 & 0.82 \\
\hline $\begin{array}{l}\text { 3. Many programs for EFL teacher in-service professional development are short-term, which is not good } \\
\text { enough to contribute to the continuity of teachers' in-service professional development. }\end{array}$ & 4.73 & 0.45 \\
\hline 4. Many programs of in-service professional development focus too much on the theories of the TEFL. & 4.55 & 0.66 \\
\hline $\begin{array}{l}\text { 5. Many programs of in-service professional development lay less emphasis on the issues existing in the } \\
\text { TEFL. }\end{array}$ & 4.58 & 0.67 \\
\hline $\begin{array}{l}\text { 6. Many programs of in-service professional development fail to serve EFL teachers' needs to solve their } \\
\text { real problems. }\end{array}$ & 4.80 & 0.45 \\
\hline $\begin{array}{l}\text { 7. Many programs of EFL teacher in-service professional development fail to offer the approaches to help } \\
\text { the EFL teachers to solve the problems directly from their daily teaching. }\end{array}$ & 4.80 & 0.52 \\
\hline $\begin{array}{l}\text { 8. EFL teachers are in the dilemma that while they want to have their in-service professional development, } \\
\text { their heavy workload often stops them from doing so. }\end{array}$ & 4.55 & 0.53 \\
\hline $\begin{array}{l}\text { 9. For some tertiary EFL teachers, their out-of-date assumption about in-service professional development } \\
\text { leads to their ignorance of personal in-service professional development. }\end{array}$ & 4.76 & 0.60 \\
\hline $\begin{array}{l}\text { 10. Some administrators do not attach importance to the EFL teachers' in-service professional } \\
\text { development, so teachers can not get support for their in-service professional development from them. }\end{array}$ & 4.60 & 0.49 \\
\hline Total & 4.64 & 0.56 \\
\hline
\end{tabular}

As shown in Table 1, a total of 55 teacher participants, all of them gave the response to these questions, 33 (60\%) strongly agreed and $22(40 \%)$ agreed that the programs were quite limited and lack of attention from administrators. Meanwhile, 30 (54.4\%) strongly agreed and 25 (45.5\%) agreed that they were in the dilemma between their training needs and heavy workload. $47(85.5 \%)$ also strongly agreed and $5(9.1 \%)$ agreed that many programs could not deal with the problems directly from their daily teaching, and some teachers had the out-of-date assumption. Likewise, 45 $(81.8 \%)$ strongly agreed and $10(18.2 \%)$ agreed that the university had to pay more for the programs off campus. Besides, $40(72.7 \%)$ strongly agreed and 15 (27.3\%) that many programs were lack of continuity. 38 (69.1\%) strongly agreed and $11(20 \%)$ agreed that many programs laid less emphasis on the issues existing in the TEFL, but focused too much on its theories.

Secondly, the open-ended questions in the questionnaire were also responded by all of the 55 teacher participants.

In terms of what kind of programs they have attended before, many teachers answered that the programs were short-term lasting only two or three days including the registration day, and in most cases, they were held during the summer or winter vacations in other cities or other provinces, which attracted more attendants with the arranged sightseeing trip rather than the academic exchange.

When it came to whether they met with any problems in their daily teaching which could not be solved by themselves, all of them thought so. One of the teacher participants wrote down like this: 
"...... In my classroom teaching, some problems are those that I can predict, and so I can prepare their solutions. However, when new problems are suddenly jumping in class, I sometimes can not solve them immediately on the spot. I have to do it after class or ignore it, I often wonder if only we have a team working together......"

With regards to whether they put their in-service professional development into agenda or what hindered their in-service professional development, 20 of them said they did so while 35 said that they did not. Those who had not taken it into their agenda did not know how to conduct it without the chance to have off-service professional development, and the heavy teaching workload and busy schedule hindered them from doing so.

As far as whether their in-service professional development could be easily carried out was considered, most of them thought that it was not easy to attend or conduct their in-service professional development although they have realized its importance. As one of them put,

"I have been teaching English for more than ten years, of course, I know the reform that our Ministry of Education is now conducting on English language teaching, with this pace, we need to innovate ourselves. But how can we do it? I have to teach over ten hours a week, two different courses. After this, I have to save some time to take care of the family, so what can I do with my professional development? I know it's important and necessary, but I don't know exactly how to do it......"

Regarding what problem should be solved first to facilitate their in-service professional development, most of them thought that a practical program or model would contribute to their in-service professional development.

\section{B. The Results from the Interview}

First of all, the 12 interviewees had a common idea that the situation of the teachers' professional development should be far better if possible when they were asked to express their opinions of the teachers' professional development in general. And although they have experienced some kind of professional development, such as, one-year or half-a-year off-service non-degree program, one-week workshop, two-day or three-day seminar, provincial or national academic conference, what they thought was that these programs failed to sustain their in-service professional development.

Secondly, while asked the question "Do you include your professional development in your career plan?" eight of them said "not yet" while the rest said "yes". Those who haven't put it into their career plan explained that they have taught English for quite a long time, and they were very skillful, and especially after getting the diploma of MA, their focus was not on this aspect, although they knew its importance, they were a little afraid of the reform, they wanted to have a peaceful and stable life, having more time taking care of their family. Those who said "yes" were somewhat different. They wanted to have an innovation in their work, and put new teaching concept into their work. They preferred to try some new methods or models, and conducted the research on their classroom teaching. Most of this group were younger than the former, and planed to improve their academic diploma, and some were preparing for the test to a $\mathrm{Ph}$. D program.

Thirdly, speaking of the detailed problems in their in-service professional development, all of them gave the examples in turn. By summarizing what they offered, they were: 1) there was the dilemma between the heavy teaching load and the in-service professional development; 2) the program was not practical; 3) the chance was not for everyone who wanted to attend; 4) the program was a kind of traveling rather than professional training; 5) the lecturer in the program paid more attention to the developed universities; 6) the program was something like competition, the participants from the developing universities were always the losers; 7) what they learned from some program could not be kept practicing in their teaching. But they thought it was necessary for EFL teachers to have in-service professional development even if they have had their pre-service professional development.

In response to Research Question 2, the same two instruments were employed for data collection, and their results were shown respectively.

\section{The Results from the Questionnaire}

The suggestions that the teacher participants agreed on for their in-service professional development were shown as follows: 
TABLE 2;

THE RESULTS OF TERTIARY EFL TEACHERS' SUGGESTIONS IN THEIR IN-SERVICE PROFESSIONAL DEVELOPMENT

\begin{tabular}{|c|c|c|}
\hline Suggestions & M & $\mathbf{S}$ \\
\hline 1. Tertiary EFL teacher in-service professional development should be put into agenda. & 4.91 & 0.29 \\
\hline $\begin{array}{l}\text { 2. Tertiary EFL teacher in-service professional development should be taken as an important process as } \\
\text { their pre-service one in their career. }\end{array}$ & 4.91 & 0.29 \\
\hline $\begin{array}{l}\text { 3. Programs for EFL teacher in-service professional development should help teachers' conceptualization } \\
\text { for new learning theories and teaching approaches. }\end{array}$ & 4.91 & 0.29 \\
\hline $\begin{array}{l}\text { 4. Programs for EFL teacher in-service professional development should contribute to solving teachers' } \\
\text { problems with effective strategies. }\end{array}$ & 4.89 & 0.37 \\
\hline $\begin{array}{l}\text { 5. In order to have effective in-service professional development, EFL teachers should have it ongoing } \\
\text { other than a short-term practice. }\end{array}$ & 4.64 & 0.48 \\
\hline $\begin{array}{l}\text { 6. What matters in EFL teacher in-service professional development is not how many times they attend the } \\
\text { relevant programs but how much they can learn from them. }\end{array}$ & 4.89 & 0.32 \\
\hline $\begin{array}{l}\text { 7. Effective tertiary EFL teacher in-service professional development should be carried out without } \\
\text { ignoring the classroom research. }\end{array}$ & 4.65 & 0.48 \\
\hline 8. Collaboration for EFL teachers in their in-service professional development should be encouraged. & 4.80 & 0.45 \\
\hline $\begin{array}{l}\text { 9. Team work is better than individual practice in terms of sustainable in-service professional } \\
\text { development. }\end{array}$ & 4.87 & 0.39 \\
\hline $\begin{array}{l}\text { 10. Peer coaching within a team teaching can be more effective with its two-layer cooperation for teachers } \\
\text { in the process of learning new knowledge and of solving the problems from their real teaching context. }\end{array}$ & 4.85 & 0.40 \\
\hline Total & 4.83 & 0.37 \\
\hline
\end{tabular}

As shown in Table 2, among the 55 respondents, 50 (90.9\%) strongly agreed and $5(9.1 \%)$ agreed that tertiary EFL teachers should plan their in-service professional development as an important process in their career and the programs should be designed for teachers' conceptualization for new learning theories and teaching approaches. 50 (90.9\%) also strongly agreed and $4(7.3 \%)$ agreed the programs should contribute to solving teachers' problems with effective strategies. Then, $36(65.5 \%)$ strongly agreed and $19(34.5 \%)$ agreed that effective tertiary EFL teacher in-service professional development should be carried out without ignoring the classroom teaching and research. Likewise, 35 (63.6\%) strongly agreed and $20(36.4 \%)$ agreed that EFL teachers should have it ongoing other than a short-term practice. $49(89.1 \%)$ strongly agreed and $6(10.9 \%)$ agreed that what mattered was what they could learn from the programs, and team work was better than individual practice in terms of sustainable in-service professional development. Meanwhile, $48(87.3 \%)$ strongly agreed and $6(10.9 \%)$ agreed that peer coaching within a team teaching could be more effective with its two-layer cooperation for teachers in the process of learning new knowledge and of solving the problems from their real teaching context. Finally, $45(81.8 \%)$ also strongly agreed and $9(16.4 \%)$ agreed that the collaboration of EFL teachers in their in-service professional development should be encouraged.

What the teacher participants wrote down to answer the open-ended questions in terms of the suggestions also offered very important information.

While asked whether they were satisfied with the programs they attended for their in-service professional development, most of them said "not always". They explained that some programs were really good in some parts, but not good enough in others. Some teachers mentioned that some programs that they had attended had more focus on the non-academic activities such as saving a whole day or longer for the on-the-spot traveling to the city or resorts in order to attract more attendants, others also mentioned that in the programs that they attended the focus of the lecture or the workshop was based on the situation of the developed areas, such as the eastern, central, or southeastern parts of China. The model or methods which could be employed effectively there might not be practical in the underdeveloped or developing areas. The respondents also offered some suggestions, such as, to organize the down-to-earth program that could solve the problems of the developing areas; teachers in eastern areas and those in western areas should be based on their different teaching contexts, and helped with each other just in some cases; university-based or school-based programs should be organized for in-service professional development.

When they were asked to answer the question "What is the ideal program or model for your in-service professional development?" most of them shared the similar idea, as what one of them put,

“....... In my opinion, the ideal program or model for our English teacher's in-service professional development should be something that can lead to a sustainable practice. It can attract us to follow it willingly and continuously, and we can have it as a base to improve our daily teaching, and to do something like research action together with our colleagues, and of course, it can help us to do more and further practice in our professional development ...."

In terms of whether they liked to work individually for their in-service professional development or with a partner or within a team, all of them answered that they would like to work with a partner, colleagues, or within a team.

\section{The Results from the Interview}

First, all of 12 interviewees said that they would like to attend such a program for their in-service professional development as this: the program should include both latest educational theories, especially those related to language teaching, and teaching practice. This was because what mattered in the in-service professional development was to have the teachers exposed to the latest theories or concepts in their field and the practice all over the world so that the teacher could share their experiences and exchange their practice, and take lessons from each other. What's more, the program should be in continuity and could be closely rooted in their daily teaching. Although they did not have any criteria of 
taking in-service professional development, they thought they should take it regularly after being a university teacher. They made such suggestions on their in-service professional development as: 1) to attend a national or international conference every year or more often; 2) to take a seminar every year or more often; 3 ) to work with a teaching team in the daily work; 4) to go for a program at any time when necessary; 5) to take a university-based program every semester with the help of the experts and the administrators. They stressed that no matter what program it was, the program should be conformed to the situation that in-service professional development was in continuity. Besides, regarding EFL teacher in-service professional development, most of the teachers thought that it should be done immediately since the field of TEFL has got very fast development. Learning English was like learning something that kept changing, it was easy for the teachers to stay behind if he or she was bad-informed, so to take instant and sustainable in-service professional development for them was quite necessary.

Second, while asked if they would like to cooperate with colleagues for their in-service professional development, all of them answered "yes", and as one of them said, "That's a good idea. Working with the colleagues is interesting, helpful, confident, and fantastic." They thought that the problem that the in-service professional development faced was that it was brokenly conducted. When the teacher got some new idea or practice from a seminar, but after returning to their normal teaching situation, in most cases, they turned to their previous ways because there was no atmosphere for them to carry out what they had learned. Therefore, if in the daily teaching they could be encouraged to do so, especially together with their colleagues, then the new teaching concepts and methods would be definitely shared and practiced in continuity.

To conclude, after knowing about the EFL teachers' current problems and suggestions, it could be said that they were more willing to attend a program based on their needs and work with peers and team members for their in-service professional development.

\section{DISCUSSION}

According to the results presented above, the problems and the suggestions on the tertiary EFL teachers' in-service professional development were discussed. The results revealed that there were many problems for the tertiary EFL teachers in their in-service professional development. In order to solve these problems, the tertiary EFL teachers also made suggestions on the way to improve their in-service professional development, which strongly showed their needs to develop a program or model to strengthen the tertiary EFL teachers' cooperation in their daily teaching so that their in-service professional development could be conducted in a practical and sustainable way.

\section{Components Affecting Tertiary EFL Teachers' In-service Professional Development}

According to the results from the questionnaire, it could be seen that the most important component that affected tertiary EFL teachers' in-service professional development was the shortage of good and practical programs. It could be argued that the EFL teachers might not be willing to attend the programs that were not practical or good enough for them to enhance their professional or teaching ability. Tusi (2003) claimed that EFL profession is facing two problems, namely, the lack of teacher training programs and the dissatisfaction with conventional theory-into-practice training models (as cited in Meng \& Tajaroensuk, 2013). Liu (2005) claimed that many training models are quite traditional in which the lecture-based training is lack of the interaction between the trainer and the trainees. As what Koch (2006) indicated, "The process must actually be effective in achieving its goals. All of the efficiency, timeliness and predictability in the world are wasted if the process is not doing what the stakeholders need of it". Therefore, many researches were conducted for the range of the professional development opportunities for teachers in order to explore or design meaningful and effective activities in professional development programs (Sandholtz 2002; Pir 2005; Starkey et al 2009).

The research results also revealed another important component that was the lack of the continuity for tertiary EFL teachers' in-service professional development, which seriously affected their in-service professional development. Richards and Farrell (2005) have claimed that development serves a long-term goal and seek to facilitate growth of teacher's understanding of teaching and of themselves as teachers. Widden et al (1996) and Day (1999) have pointed out that the nature of teaching needs continuing career-long professional development role of the teacher in changing contexts in which teachers work and learning took place. This implied that people working in a profession like teaching may have more demanding expectations of themselves and their colleagues because they regard the process of professional development as continuous and on-going (Wallace, 1998).

The contradiction between tertiary EFL teachers' heavy workload and their desire to have in-service professional development was also found to be another component affecting their in-service professional development. Many empirical studies indicated that time and workload are common critical factors that teachers encounter in continuous professional development (Carney, 2003). Heavy workload is considered as a common problem for public education as a result of a stressful environment that discourages teachers from participating in continuous professional development in their busy professional lives (Quaglia et al., 1991; Day \& Gu, 2010). This implied that the school should give more time for facilitating teachers' continuous professional development by allowing continuous professional development activities to be conducted within school hours and arranging time for teachers to have more space in engaging in continuous professional development activities (Wan, 2011). 
Additionally, the contradiction between the university's financial support and the expense for the programs became another component that affected tertiary EFL teachers' in-service professional development. Implementing EFL teacher in-service professional development usually cost the university more simply because most of the programs were offered in other places. Yu et al (2009) have claimed that it is a fact that considerable investment on hardware and software has provided a rich material supply for the new mode of English instruction. Nevertheless, the key factor which makes best use of the cost-consuming equipment, effectively integrating modern technology into course instruction is none other than the teacher. This implied that the authorities of the university should attach more importance to the EFL teachers' in-service professional development so that the teachers could make good use of the equipment for better instruction.

\section{Problems of Tertiary EFL Teachers' In-service Professional Development}

In terms of the problems of tertiary EFL teachers' in-service professional development, the research results showed that tertiary EFL teachers did not have a practical and sustainable model for their in-service professional development.

The participants' opinions about the current problems in their in-service professional development and the suggestions they made revealed the fact that they needed a practical and sustainable program or model for their in-service professional development based on their real needs in their teaching context. This was consistent with many researchers, such as Villegas-Reimers (2003), Schwille and Dembélé (2007), etc. It has been found in their studies that many traditional on-the-job teacher professional development programs are conducted in such ways as workshops, seminars, conferences or courses. With the characteristics of being brief, fragmented, incoherent encounters, these programs have been criticized for being decontextualised and isolated from real teaching context. This implied that the tertiary EFL teachers needed not only their in-service professional development but also the satisfactory programs for their in-service professional development.

According to Breen (2007), professional development is now at a critical moment, for it is the arena in which teachers can freely explore ways of thinking and acting collegially that focus upon the positive opportunities of the present climate of change. But how could the tertiary EFL teachers participate in the ideal programs that they thought useful for their in-service professional development? Strategies for teacher development often involved documenting different kinds of teaching practices; reflective analysis of teaching practices, examining beliefs, values, and principles; conversation with peers on core issues; and collaborating with peers on classroom projects. Professional development should go beyond personal and individual reflection (Richards \& Farrell, 2005). As far as EFL teachers' professional development was concerned, more elements should be taken into account, as what Richards (2008) claimed, "the profession of English language teaching requires a specialized knowledge base obtained through both academic study and practical experience, and it is a field of work where membership is based on entry requirements and standards." And Brown (2000) also stressed that language teachers should be aware of the fact that language learning and teaching always went together. Therefore, it was implied that updating the professional knowledge was inevitable and the cooperation with colleagues could be encouraged for the tertiary EFL teachers' in-service professional development.

\section{Suggestions Made by Tertiary EFL Teachers for Their In-service Professional Development}

The research results also revealed that the tertiary EFL teachers were not satisfied with the programs they had attended for their in-service professional development, and the suggestions they made to improve their in-service professional development were very constructive.

It was suggested that tertiary EFL teacher in-service professional development should be put into agenda, and it should be taken as an important process as their pre-service one in their teaching career. Professional development "serves a long-term goal and seeks to facilitate growth of teacher's understanding of teaching and of themselves as teachers" (Richards \& Farrell, 2005). It may also have different intended outcomes including enhancing professional skills and understandings; updating the teaching profession; and supporting major educational changes and reforms that have an impact on teaching practice (Dall'Alba \& Sandberg, 2006). While pre-service TEFL programs offered student teachers tailored and highly specialized knowledge in language and linguistics, TEFL methodology and testing, practice teaching, and a variety of other areas depending on the program, and teachers were prepared with the knowledge base (Freeman \& Johnson, 1998), effective and meaningful in-service professional development opportunities were critical to the successful implementation of any change agenda (Peixotto \& Fager, 1998).

This study also showed the suggestion that the programs should help teachers' conceptualization for new learning theories and teaching approaches, and contribute to solving teachers' problems. This implied that the ideal program should serve as a platform that the teachers could have it as a base to update their professional knowledge, improve their daily teaching and do research action together with their colleagues. According to Leung and Teasdale (1999), ESL/EFL teachers required sound professional knowledge, including knowledge of language used in curriculum contexts, knowledge of second language acquisition principles, knowledge of pedagogic and assessment principles and skills in the management of the social aspects of working with learners and colleagues, and such professional knowledge needs updating and improving. James (1973) ascertained that it was only through the growth of in-service training that this gulf between advancing knowledge and practice could be bridged. Good in-service professional development programs, such as INSET, could be classified into three groups: 1. Professional education, by which is meant a widening and deepening of a teacher's theoretical perspectives by means of advanced study. 2. Professional training, the development of the knowledge and skills which are of direct applicability to daily work. 3. Professional support, activities aimed at developing on-the-job experience and performance (Spence 1996, cited in Yigit, 2008). 
The suggestion was also highlighted by recommending the strategy of collaboration for EFL teachers in their in-service professional development, and it was suggested that team work was better than individual practice in terms of sustainable in-service professional development. Teams that work collaboratively can obtain greater resources, recognition and reward when facing competition for finite resources (Wagnar \& Leydesdorff, 2005). As teachers learn to learn from one another and interact around substantive issues of teaching and learning and their own professional growth, their joint insights may shift the emphasis from individual classroom innovations to contributions to the teaching profession, resulting in organizational learning and change for the benefit of students (Collinson \& Cook, 2004 cited in Nira et al, 2008). Therefore, encouraging the tertiary EFL teachers to have cooperation in their in-service professional development may contribute to its continuity and persistence.

\section{CONCLUSION}

This study has been conducted to investigate the current problems that the tertiary EFL teachers have in their in-service professional development and the suggestions that they make on it, and then to make the preparation for finding a way to solve these problems in the follow-up research of this present study. Its results have helped to pave the way for more research on EFL teachers' professional development. It is found that the current problems that the tertiary EFL teachers were faced with really blocked their in-service professional development, and the suggestions that they made were based on their demands and their teaching context, which would be helpful and constructive to design a training program or develop a model for their in-service professional development. Moreover, further studies are needed to solve these problems in the tertiary EFL teacher in-service professional development, and the efficiency of the approach to the solutions of these problems should be examined.

\section{ACKNOWLEDGMENT}

The authors wish to thank Dr. Sirinthorn Seepho for providing very helpful suggestions. They also want to thank the EFL teachers from Guiyang University, China, who were the main participants of this study.

\section{REFERENCES}

[1] Ball, D.L. \& Cohen, D.K. (1999). Developing practice, developing practitioners: toward practice-based theory of professional education. In L. Darling-Hammond \& G. Sykes (Eds). Teaching as the learning profession: handbook of policy and practice. San Francisco: Jossey Bass, 3-32.

[2] Breen, M. P. (2007). Appropriating Uncertainty: ELT Professional Development in the New Century. In J. Cummins \& C. Davison (Eds.) International handbook of English Language Teaching. Springer Science + Business Media, LLC, 1067-1084.

[3] Brown, H.D. (2000). Principles of Language Learning and Teaching. White Plains, NY: Addison Wesley Longman.

[4] Carney, S. (2003). Learning from school-based teaching training: possibilities and constraint for experienced teachers. Scandinavian Journal of Education Research, 47(4), 413-429.

[5] CERNET. (2001). Chinese Universities Enroll 2.6 Million Freshmen. Education in China. http://www.edu.cn/200111_1473 /20060323/t20060323_20256.shtml (accessed 28/2/2013).

[6] Collinson, V. \& Ono, Y. (2001). Professional development of teachers in United States and Japan. European Journal of Teacher Education, 24, 223-248.

[7] Dall'Alba, G. \& Sandberg, J. (2006). Unveiling Professional Development: A Critical Review of Stage Models. Review of Educational Research, 76, 383-412.

[8] Day, C. (1999). Developing Teachers: The Challenges of Life-long Learning. London: Falmer Press.

[9] Day, C. \& Gu, Q. (2010). The New Lives of Teachers. London: Routledge.

[10] Feiman-Nemser, S. (2001). From preparation to practice: designing a continuum to strengthen and sustain teaching. Teachers College Record, 103, 1013-1055.

[11] Freeman, D. \& Johnson, K.E. (1998) Reconceptualizing the knowledge-base of language teacher education, TESOL Quarterly 32, 397-41.

[12] Fullan, M. \& Hargreaves, A. (1996). What's worth fighting for in your school. New York: Teachers College Press.

[13] James, L. (1973). The James Report's Third Cycle. In In-Service Training: Structured Context, Watkins, (Eds.) London: Ward Lock Educational, 12-19.

[14] Koch, A.S. (2006). High-quality Process. http://www.cmcrossroads.com/content/view/6824/135/ (accessed12/8/2010).

[15] Leung, C. \& Teasdale, A. (1999). ESL teacher competence: professional education and the nature of professional knowledge. Theory in Language Teacher Education. In H. Trappes-Lomax \& I. McGrath (Eds), Essex: Pearson Education, 57-69.

[16] Li, B. \& Hudson, P. (2011) Understanding Chinese TEFL academics' capacity for research. Journal of Further and Higher Education, 35(3), 391-407.

[17] Liu, G. Z. (2005). The Trend and Challenge for Teaching EFL at Taiwanese Universities. Regional Language Centre Journal, $36(2), 211-221$.

[18] Liu, X. (2006). Exploration of issues and models of new curriculum training for rural junior high school English teachers, Foreign Language Teaching and Research in Basic Education, 70(12), 51-53.

[19] Meng, J.Y. \& Tajaroensuk, S. (2013). The workshop in the multilayered peer coaching model for tertiary EFL teachers' in-service professional development. English Language Teaching, 6(8): 44-53 http://dx.doi.org/10.5539/elt.v6n8p44.

[20] Meng, J.Y., Tajaroensuk, S., \& Seepho, S. (2013). The multilayered peer coaching model and the in-service professional development of tertiary EFL teachers. International Education Studies, 6(7): 18-31 http://dx.doi.org/10.5539/ies.v6n7p18. 
[21] Nira, A. E. \& Boglerb, R. (2008). The Antecedents of Teacher Satisfaction with Professional Development Programs. Teaching and Teacher Education, 24, 377-386.

[22] Ono, Y. \& Ferreira, J. (2010). A case study of continuing teacher professional development through lesson study in South Africa. South African Journal of Education, 30, 59-74.

[23] Peixotto, K. \& Fager, J. (1998). High Quality Professional Development. Portland, OR: Northwest Regional Educational Laboratory.

[24] Pir, G. (2005). A Model of Inservice Training for University Teachers. Gomal University Journal of Research, 21, 74-76

[25] Quaglia, R., Marion, S., \& McIntire, W. (1991). The relationship of teacher satisfaction to perceptions of school organization, teacher empowerment, work conditions, and community status. Education, 112, 206-217.

[26] Richards, J. C. (2008). Second Language Teacher Education Today. RELC. Singapore: Sage Publication, 39(2), $158-177$.

[27] Richards, J. C., \& Farrell, T. S. (2005). Professional Development for Language Teachers: Strategies for Teaching Learning. Cambridge: Cambridge University Press.

[28] Schwille, J. \& Dembélé, M. (2007). Global perspectives on teacher learning: improving policy and practice. Paris: UNESCO International Institute for Educational Planning.

[29] Starkey, L., Meyer, L. H., Yates, A. Hall, C. Taylor, M. Stevens, S. \& Toia, R. (2008). Professional Development Design: Embedding Educational Reform in New Zealand. Teaching and Teacher Education, 25,181-189.

[30] Stockton, C.M. (2007). Successful Professional Development Model Components in Two High Achieving Missouri School Districts. Ph.D dissertation, Wichita State University, USA.

[31] Tsui, A. B.M. (2003). Understanding expertise in teaching. New York: Cambridge University Press

[32] Villegas-Reimers, E. (2003). Teacher professional development: an international review of the literature. Paris: UNESCO International Institute for Educational Planning.

[33] Wagner, C. S., \& Leydesdorff, L. (2005). Network Structure, Self-Organization and the Growth of International Collaboration in Science. Research Policy, 34(10), 1608-1618.

[34] Wallace, M. J. (1998). Action Research for Language Teachers. Cambridge: Cambridge University Press.

[35] Wan, W.Y. (2011). Teachers' Perceptions and Experiences of Continuing Professional Development (CPD):Opportunities and Needs in Hong Kong Primary Schools. Ph. D Dissertation, University of Nottingham.

[36] Wen, Q.F. \& Ren, Q.M. (2010). On the tertiary EFL teacher in-service professional development in China: Trends, Characteristics, Problems and Solutions -- By reviewing the related literature from 1999 to 2009. FLC. 7(4), 77-83.

[37] Widden, M.F., Mayer-Smith, J.A., \& Moon, B.J. (1996). Knowledge, Teacher Development and Change. In Teachers' Professional Lives, In I. F. Goodson \& A. Hargreaves (Eds.). London: Falmer Press, 187-205.

[38] Yigit, N. (2008). A Study on Evaluation of Effectiveness of an In-service Training (INSET) Course about the Use of Instructional Technologies and Material Development. World Applied Sciences Journal, 4 (Supple 1), 69-75.

[39] Yu, L., Wang, J.W., \& Zeng, X.S. (2009). Teachers' Information Literacy: Key to Technology-Course Integration. CAFLEC. $129,70-74$.

[40] Zhang, Z. \& Li, S. (2003). English teacher development, Curriculum, Teaching Material and Method, 23(11), 59-66.

[41] Zheng, H.Y. (2010). Dilemmas in Teacher Development in the Chinese EFL Context. Journal of Cambridge Studies, 7(2), $2-13$.

Junyi Meng is a Ph. D candidate in English Language Studies at School of Foreign Languages in Institute of Social Technology of Suranaree University of Technology, Thailand. She received her MA degree in Master of Art in Teaching from Oakland University, Michigan, USA, in1998. She is a faculty member of School of Foreign Languages at Guiyang University, Guizhou, China. Her research interests include language teaching methodology, TEFL and teacher training.

Songphorn Tajaroensuk is an associate professor of School of Foreign Languages, Institute of Social Technology, Suranaree University of Technology (SUT), Thailand, and she is the former Dean of Institute of Social Technology, SUT. She obtained her M.A. in English in Chulalongkorn University, Thailand, and M. A. in TEFL in Southern Illinois University, USA. She has been teaching and supervising MA and Ph. D students in English Language Studies for more than ten years. Her research field is TEFL and teacher training. 